\title{
Obesitas sentral berhubungan dengan toleransi glukosa terganggu pada remaja perempuan
}

\author{
Central obesity is associated with impaired glucose tolerance in female adolescents
}

Lucia Mawarti Dwi Astuti ${ }^{1}$, Endy Paryanto Prawirohartono ${ }^{1}$, Noormanto ${ }^{1}$, Madarina Julia ${ }^{1}$

\begin{abstract}
Background: Obesity in adolescents has become health problem in Indonesia. Central obesity is associated with insulin resistance. Theoretically, insulin resistance will cause impaired glucose tolerance (IGT) and could develop into type 2 diabetes.

Objective: The aim of this study were to evaluate the difference in IGT prevalence between central and non central obesity and to identify the risk factors associated with IGT.

Method: A cross sectional study was conducted at 3 private secondary schools in Yogyakarta and recruited 62 obese female students aged 12-18 years. The subjects were classified into central obesity (BMI/U> +2SD and waist circumference $>p 90)$ and non central obesity based on anthropometric data. Fasting glucose and 2 hours after loading were measured in all subjects. Differences in the proportion of IGT between the two groups was calculated by Chi-square test and risk factors associated with IGT were calculated by multivariate logistic regression with $95 \%$ confidence interval.

Results: Of 62 subjects, 14 of them have IGT and the prevalence of IGT was significantly higher in the central obesity group compared to non central obesity group (11/31 vs $3 / 31, p=0.03)$. Central obesity was found to be the only risk factor of IGT (OR=4.6; $95 \% \mathrm{Cl}: 1.04$ to 20.24). Twenty one of the subjects were found to have impaired fasting glucose (IFG) (34\%) and one subject (1.6\%) had IFG+IGT. There were no differences in the proportion of IFG between central and non central obesity groups.
\end{abstract}

Conclusion: The prevalence of IGT in female students with central obesity was higher compared to those with non central obesity. A female student with central obesity had 4.6-fold risk of having IGT compared to those with non central obesity.

KEY WORDS central obesity, impaired glucose tolerance, female student, prevalence, cross sectional study, impaired fasting glucose

\begin{abstract}
ABSTRAK
Latar belakang: Masalah obesitas, terutama obesitas sentral pada remaja sudah menjadi masalah kesehatan. Obesitas sentral berhubungan dengan risiko resistensi insulin, sementara resistensi insulin akan mengakibatkan toleransi glukosa terganggu (TGT) yang akhirnya dapat berkembang menjadi diabetes mellitus (DM) tipe 2.

Tujuan: Tujuan penelitian adalah untuk menilai perbedaan kejadian TGT pada remaja perempuan dengan obesitas sentral dibandingkan dengan remaja perempuan tanpa obesitas sentral, serta untuk menilai faktor risiko terjadinya TGT.

Metode: Dilakukan survei potong lintang pada 3 sekolah menengah swasta di Yogyakarta. Berdasarkan skrining tersebut diperoleh 62 siswa perempuan obes berusia 12-18 tahun. Subjek dikelompokkan menjadi: dengan obesitas sentral (IMT/U >+2SD dan ukuran lingkar pinggang >90 cm) dan tanpa obesitas sentral. Semua subjek menjalani pemeriksaan gula darah puasa dan 2 jam pasca pembebanan. Perbedaan proporsi di antara kedua kelompok diuji dengan uji Chikuadrat. Faktor risiko terjadinya TGT pada kedua kelompok dihitung dengan OR (IK 95\%).

Hasil: Prevalensi TGT secara keseluruhan adalah 14 dari 62 subjek. Prevalensinya jauh lebih besar pada penderita obesitas sentral daripada yang tanpa obesitas sentral (11 dari 31 dibanding 3 dari 31, $p=0,03$ ). Obesitas sentral merupakan satu-satunya faktor risiko TGT (OR=4,6; IK95\%:1,04-20,24). Ada subjek penelitian yang menderita glukosa puasa terganggu (GPT) yaitu 21 dari 62 subjek. Ada satu subjek yang menderita gabungan antara GPT dan TGT.

Kesimpulan: Prevalensi TGT pada remaja perempuan obes lebih tinggi pada penderita obesitas sentral daripada tanpa obesitas sentral. Remaja perempuan dengan obes sentral memiliki resiko 4,6 kali lebih besar untuk menderita TGT dibandingkan dengan remaja perempuan dengan obes non sentral.
\end{abstract}

KATA KUNCl: obesitas sentral, toleransi glukosa terganggu, remaja perempuan, prevalensi, studi cross sectional, glukosa puasa terganggu

\section{PENDAHULUAN}

Obesitas pada anak dan remaja telah menjadi masalah kesehatan di seluruh dunia (1). Menurut hasil penelitian, prevalensi obesitas siswa sekolah menengah di Kota Yogyakarta mengalami peningkatan 3\% selama kurun waktu 2 tahun (2). Pada anak dan remaja obes, kelebihan
${ }^{1}$ Bagian Anak Rumah Sakit Umum Pusat Dr. Sardjito/Fakultas Kedokteran Universitas Gadjah Mada, Jl.Kesehatan No 1 Yogyakarta 55281, Telp (0274) 561616, e-mail: lucia.ismartanto@gmail.com*, prawirohartonoendypyt@ yahoo.co.id, madarinajulia@yahoo.com

*correspondence author 
lemak kemungkinan besar terakumulasi di regio abdomen $(3,4)$. Indikator antropometri banyak diteliti untuk menilai lemak viseral dan yang terbaik adalah lingkar pinggang $(5,6)$. International Diabetes Federation (IDF) menetapkan lingkar pinggang dengan batas persentil ke-90 (5) sebagai cut-off point obesitas sentral. Prevalensi obesitas sentral dari penelitian bervariasi antara $20-95 \%$, tergantung lokasi penelitian dan definisi yang digunakan.

Obesitas sentral secara patofisiologis terkait dengan resistensi insulin atau penurunan sensitivitas insulin yang merupakan risiko terjadinya toleransi glukosa terganggu (TGT) (7). Penurunan sensitivitas insulin perifer ini terbukti berhubungan dengan lemak viseral (8).

Sejauh ini penulis belum menemukan penelitian tentang obesitas sentral dan TGT pada remaja di Indonesia, khususnya di Yogyakarta. Penelitian ini bertujuan untuk membuktikan adanya hubungan antara obesitas sentral dan kejadian TGT pada remaja perempuan. Remaja perempuan dipilih karena metabolisme glukosanya sangat dipengaruhi oleh status pubertas. Selain itu, lebih mudah membedakan remaja perempuan yang sudah melewati masa pubertas dengan status menstruasinya.

\section{BAHAN DAN METODE}

Penelitian ini menggunakan desain potong lintang. Populasi penelitian adalah remaja putri di 3 sekolah menengah swasta di Yogyakarta dengan kriteria inklusi: siswa perempuan berusia antara 12-18 tahun; mengalami obesitas yang dinyatakan dengan body mass index (BMI) per umur lebih dari +2SD (BMI/U>+2SD); tidak dalam pengobatan hidroklorotiazid, kortikosteroid, beta 2 agonis (albuterol, salbutamol, dan procaterol), propanolol, fluoxetin, obat antidiabetes atau fenitoin; telah mengalami menarche (menstruasi yang pertama); dan setuju untuk mengikuti penelitian dengan menandatangani proxy-consent dari orangtua. Kriteria eksklusi adalah: menderita diabetes mellitus (DM) yang dinyatakan dengan pemeriksaan kadar glukosa darah puasa lebih dari $126 \mathrm{mg} /$ dl dan kadar glukosa 2 jam pasca pembebanan lebih dari $200 \mathrm{mg} / \mathrm{dl}$. Sekolah dipilih berdasarkan alasan kemudahan lokasi dan perizinan.

Berdasarkan perhitungan dengan rumus beda dua proporsi (9) sebesar 0,31 dengan tingkat kepercayaan 95\% dan kekuatan uji 80\% maka dibutuhkan subjek sebanyak 31 orang untuk masing-masing kelompok obesitas sentral dan obesitas non sentral. Pengukuran tinggi badan, berat badan, dan lingkar pinggang dilakukan bersama dengan pengambilan data identitas subjek. Tinggi badan diukur dalam posisi berdiri dengan subjek memakai seragam sekolah tanpa jaket, topi, sepatu, dan kaus kaki dengan ketepatan 0,5 cm. Berat badan diukur dengan memakai seragam sekolah tanpa jaket, topi, sepatu, dan kaus kaki, serta semua isi kantung dikeluarkan dengan ketepatan
0,5 kg. Lingkar pinggang diukur dengan posisi berdiri sesuai kriteria Wolrd Health Organization (WHO) dengan ketepatan 0,1 cm. Data kadar glukosa darah puasa dan 2 jam pasca pembebanan dikumpulkan setelah diperoleh persetujuan orangtua siswa. Bila jumlah subjek melebihi besar sampel maka dilakukan pengambilan sampel secara acak dengan simple random sampling.

Semua siswa yang memenuhi syarat sebagai subjek penelitian dikelompokkan dalam kelompok obesitas sentral dan kelompok obesitas non sentral. Pada kedua kelompok dilakukan pemeriksaan kadar glukosa dengan dua kali pengambilan sampel darah kapiler. Sampel pertama diambil saat subjek menjalani puasa minimal 8 jam, sampel kedua diambil 2 jam pasca pembebanan glukosa 1,75 gram/kg BB (maksimal 75 gram). Pengukuran kadar glukosa darah menggunakan glukometer Accuchek, dengan metode enzimatik glukosa dehidrogenase yang direkomendasikan oleh American Diabetes Association (ADA) 2002. Dari hasil pemeriksaan glukosa darah puasa dan 2 jam pasca pembebanan, subjek dikelompokkan ke dalam kelompok TGT dan kelompok tidak TGT. Setelah data TGT dan variabel lain terkumpul dilakukan analisis data terhadap proporsi TGT kedua kelompok dan faktor risiko yang berhubungan dengan TGT.

Variabel bebas dalam penelitian ini yaitu obesitas sentral. Seorang siswa perempuan dinyatakan mengalami obesitas sentral bila memiliki BMI lebih dari +2SD dan lingkar pinggang lebih dari $90 \mathrm{~cm}$, sedangkan yang bukan obesitas sentral bila memiliki BMI lebih dari +2SD dan lingkar pinggang kurang dari atau sama dengan 90 cm. Variabel tergantung adalah TGT yang dinyatakan sebagai kadar glukosa darah puasa kurang dari 100 mg/ dl dan kadar glukosa 2 jam pasca pembebanan lebih dari $140 \mathrm{mg} / \mathrm{dl}$ dan kurang dari $200 \mathrm{mg} / \mathrm{dl}$. Kriteria lain untuk metabolisme glukosa adalah GDN (glukosa darah normal): kadar glukosa puasa kurang dari $100 \mathrm{mg} / \mathrm{dL}$ dan kadar glukosa 2 jam pasca pembebanan lebih dari 140 mg/dL; GPT (glukosa puasa terganggu): kadar glukosa puasa lebih dari $100 \mathrm{mg} / \mathrm{dL}$ dan kadar glukosa 2 jam pasca pembebanan kurang dari $140 \mathrm{mg} / \mathrm{dL}$; GTT (tes glukosa toleransi terganggu): kadar glukosa 2 jam pasca pembebanan lebih dari $140 \mathrm{mg} / \mathrm{dL}$ dan kurang dari $200 \mathrm{mg} /$ dL; GPT+TGT: kadar glukosa puasa lebih dari $100 \mathrm{mg} /$ $\mathrm{dL}$ dan kadar glukosa 2 jam pasca pembebanan lebih dari 140 mg/dL dan kurang dari 200 mg/d; DM: kadar glukosa puasa lebih dari $126 \mathrm{mg} / \mathrm{dL}$ dan atau kadar glukosa 2 jam pasca pembebanan lebih dari $200 \mathrm{mg} / \mathrm{dl}$.

Variabel lain dalam penelitian ini ialah klasifikasi berat badan lahir berdasarkan umur kehamilan, riwayat keluarga dengan DM, riwayat diabetes gestasional saat subjek dalam kandungan, dan pubertas yang dinyatakan sebagai variabel luar. Subjek dinyatakan kecil untuk masa kehamilan (KMK) bila kurang dari atau sama dengan persentil ke-10 berdasarkan kurva berat badan lahir menurut umur 
Tabel 1. Karakteristik dasar subjek penelitian

\begin{tabular}{|c|c|c|}
\hline Karakteristik & $\begin{array}{l}\text { Obesitas sentral } \\
\quad(n=31)\end{array}$ & $\begin{array}{l}\text { Obesitas non sentra } \\
\qquad(n=31)\end{array}$ \\
\hline Usia (tahun), mean (SD) & $14,6(1,66)$ & $14,95(1,93)$ \\
\hline $\mathrm{BMI}\left(\mathrm{kg} / \mathrm{m}^{2}\right)$, mean $(\mathrm{SD})$ & $33,6(4,12)$ & $29,71(2,28)$ \\
\hline Tinggi badan (cm), mean (SD) & $158,4(5,59)$ & $156,32(5,65)$ \\
\hline Berat badan (kg), mean (SD) & $84,6(13,29)$ & $72,61(6,30)$ \\
\hline Lingkar pinggang $(\mathrm{cm})$, mean (SD) & $95,3(7,57)$ & $83,02(4,73)$ \\
\hline Kadar glukosa puasa (mg/dl), mean (SD) & $97,78(6,98)$ & $100,26(8,54)$ \\
\hline Kadar glukosa 2 jpp* (mg/dl), mean (SD) & $118,00(23,20)$ & $107,29(18,73)$ \\
\hline \multicolumn{3}{|l|}{ Riwayat keluarga DM, n (\%) } \\
\hline Ya & $6(19)$ & $6(19)$ \\
\hline Tidak & $25(81)$ & $25(81)$ \\
\hline Tidak tahu & $0(0)$ & $0(0)$ \\
\hline \multicolumn{3}{|l|}{ Diabetes gestasional, $\mathrm{n}(\%)$} \\
\hline Ya & $0(0)$ & $0(0)$ \\
\hline Tidak & $31(100)$ & $31(100)$ \\
\hline Tidak tahu & $0(0)$ & $0(0)$ \\
\hline \multicolumn{3}{|l|}{ Pubertas, n (\%) } \\
\hline Ya & $1(1,6)$ & $0(0)$ \\
\hline Tidak & $30(98,4)$ & $31(100)$ \\
\hline Tidak tahu & $0(0)$ & $0(0)$ \\
\hline \multicolumn{3}{|l|}{ Riwayat KMK, n (\%) } \\
\hline $\mathrm{Ya}$ & $0(0)$ & $1(3,2)$ \\
\hline Tidak & $31(100)$ & $30(96,8)$ \\
\hline Tidak tahu & $0(0)$ & $0(0)$ \\
\hline
\end{tabular}

Keterangan: jpp* = jam pasca pembebanan

$$
\begin{aligned}
& \mathrm{n} \quad=\text { jumlah sampel } \\
& \text { mean }=\text { rerata } \\
& \mathrm{SD}=\text { standar deviasi } \\
& \mathrm{DM}=\text { diabetes mellitus } \\
& \text { KMK = kecil untuk masa kehamilan }
\end{aligned}
$$

kehamilan, besar untuk masa kehamilan (BMK) bila lebih dari atau sama dengan persentil ke-90 berdasarkan kurva berat badan lahir menurut umur kehamilan, dan sesuai masa kehamilan (SMK) bila di antara persentil ke-10 sampai dengan persentil ke-90 kurva berat badan lahir menurut umur kehamilan berdasarkan kurva pertumbuhan dari Lubchenco (10). Ada riwayat keluarga DM bila ada anggota keluarga langsung (ayah, ibu, saudara kandung) terdiagnosis oleh dokter menderita DM, dan tidak ada riwayat keluarga DM bila tidak ada anggota keluarga langsung yang terdiagnosis oleh dokter menderita DM. Subjek dinyatakan ada riwayat diabetes gestasional bila ada riwayat kadar gula darah tinggi atau penyakit diabetes pada saat subjek dalam kandungan yang dinyatakan oleh dokter, dan tidak ada riwayat diabetes gestasional bila tidak ada riwayat kadar gula darah tinggi atau penyakit diabetes pada saat subjek dalam kandungan yang dinyatakan oleh dokter. Ada kondisi mendekati pubertas bila subjek belum mengalami menstruasi, dan tidak mendekati pubertas bila telah mengalami menstruasi teratur.

Analisis univariat dalam bentuk frekuensi dan persentase digunakan untuk data karakteristik dasar subjek penelitian. Uji hipotesis menggunakan Chisquare test atau Fisher exact test (9) sedangkan untuk menghitung faktor risiko yang berhubungan dengan TGT digunakan regresi logistik multivariat dengan interval kepercayaan 95\%. Luaran primer penelitian ini ialah perbedaan prevalensi TGT pada kelompok obesitas sentral dan kelompok obesitas non sentral. Sedangkan luaran sekunder ialah prevalensi kelainan glukosa darah yang lain. Penelitian telah mendapatkan persetujuan dari Komite Etik Penelitian Kedokteran dan Kesehatan Fakultas Kedokteran Universitas Gadjah Mada.

\section{HASIL}

Diperoleh subjek sebanyak 31 orang untuk masingmasing kelompok obesitas sentral dan obesitas non sentral. Data karakteristik subjek penelitian dapat dilihat pada Tabel 1. Berdasarkan populasi tersebut didapatkan prevalensi TGT yang lebih besar pada kelompok obesitas sentral dan bermakna secara statistik yaitu 11/31 pada subjek dengan obesitas sentral dan $3 / 31$ pada subjek dengan obesitas non sentral $(p=0,03)$ (Tabel 2).

Penulis melakukan analisis multivariat untuk mengidentifikasi variabel independen yang berhubungan dengan TGT. Analisis dilakukan pada subjek dengan TGT terhadap subjek dengan GDN (total 41 subjek, 23 subjek dengan obesitas sentral dan 18 subjek dengan obesitas non sentral). Analisis regresi logistik dilakukan untuk mengidentifikasi faktor risiko yang mempengaruhi TGT. 
Tabel 2. Prevalensi TGT dan abnormalitas glukosa darah yang lain menurut kelompok obesitas

\begin{tabular}{|c|c|c|c|}
\hline Klasifikasi & $\begin{array}{c}\text { Obesitas } \\
\text { sentral } \\
(n=31)\end{array}$ & $\begin{array}{l}\text { Obesitas non } \\
\text { sentral }(n=31)\end{array}$ & p \\
\hline \multicolumn{4}{|l|}{ GDN , n (\%) } \\
\hline Ya & 12 (39) & $15(48,4)$ & 0,61 \\
\hline Tidak & $19(61)$ & $16(51,6)$ & \\
\hline \multicolumn{4}{|l|}{ TGT, n (\%) } \\
\hline $\mathrm{Ya}$ & $11(35,5)$ & $3(9,7)$ & 0,03 \\
\hline Tidak & $20(64,5)$ & $28(90,3)$ & \\
\hline \multicolumn{4}{|l|}{ GPT, n (\%) } \\
\hline Ya & $8(25,8)$ & $13(41,9)$ & 0,28 \\
\hline Tidak & $23(74,2)$ & $18(58,1)$ & \\
\hline \multicolumn{4}{|l|}{ GTT, n (\%) } \\
\hline Ya & $11(35,5)$ & $4(12,9)$ & 0,08 \\
\hline Tidak & $20(64,5)$ & $27(87,1)$ & \\
\hline \multicolumn{4}{|c|}{ GPT+ TGT, n ( \%) } \\
\hline $\mathrm{Ya}$ & $0(0)$ & $1(3,2)$ & $0,50^{*}$ \\
\hline Tidak & $31(100)$ & $30(96,8)$ & \\
\hline \multicolumn{4}{|l|}{ DM, n (\%) } \\
\hline Ya & $0(0)$ & $0(0)$ & - \\
\hline Tidak & 31 (100) & 31 (100) & \\
\hline
\end{tabular}

Keterangan: * Fisher's exact test

Obesitas sentral $=\mathrm{BMI}>+2 \mathrm{SD}$ dan lingkar pinggang $>$ persentil ke-90

GDN (glukosa darah normal) = kadar glukosa puasa $<100 \mathrm{mg} / \mathrm{dL}$ dan kadar glukosa 2 jam pasca pembebanan $<140 \mathrm{mg} / \mathrm{dL}$

GPT (glukosa puasa terganggu) = kadar glukosa puasa $>100 \mathrm{mg} / \mathrm{dL}$ dan kadar glukosa 2 jam pasca pembebanan $<140 \mathrm{mg} / \mathrm{dL}$

GTT (tes glukosa toleransi terganggu) $=$ kadar glukosa 2 jam pasca pembebanan $>140 \mathrm{mg} / \mathrm{dL}$ dan $<200 \mathrm{mg} / \mathrm{dL}$

TGT (toleransi glukosa terganggu) = kadar glukosa puasa $<100 \mathrm{mg} / \mathrm{dL}$ dan kadar glukosa 2 jam pasca pembebanan $>140 \mathrm{mg} / \mathrm{dL}$ dan $<200 \mathrm{mg} / \mathrm{dL}$ GPT+TGT $=$ kadar glukosa puasa $>100 \mathrm{mg} / \mathrm{dL}$ dan kadar glukosa 2 jam pasca pembebanan $>140 \mathrm{mg} /$ $\mathrm{dL}$ dan $<200 \mathrm{mg} / \mathrm{dL}$

$\mathrm{DM}=$ kadar glukosa puasa $>126 \mathrm{mg} / \mathrm{dL}$ dan atau kadar glukosa 2 jam pasca pembebanan $>200$ $\mathrm{mg} / \mathrm{dl}$

Hasil analisis menunjukkan obesitas sentral adalah satusatunya faktor risiko yang mempengaruhi TGT dengan OR=4,58 (IK 95\%:1,04-20,24; p=0,03). Namun demikian OR dengan rentang yang sangat lebar menunjukkan kemungkinan besar sampel yang kurang memadai.

\section{BAHASAN}

Penelitian ini berhasil membuktikan adanya hubungan antara obesitas sentral dengan TGT. Hal ini sesuai dengan hasil penelitian sebelumnya di Yogyakarta yang melaporkan prevalensi resistensi insulin pada remaja putri dengan obesitas sentral lebih tinggi dibandingkan yang obesitas non sentral (11). Hasil penelitian ini juga sesuai dengan penelitian di Brazil (6) yang menunjukkan bahwa pada obesitas sentral, mobilisasi asam lemak bebas terjadi lebih cepat dan langsung berhubungan dengan sistem portal sehingga terjadi penurunan ekstraksi insulin yang menyebabkan hiperinsulinemia sistemik dan memacu glukoneogenesis.

Di sisi lain menurut hasil penelitian di Amerika Serikat (7), pada obesitas sentral terjadi peningkatan sitokin terutama TNF- $\alpha$ dan IL-6 yang berakibat pada meningkatnya lipolisis dan pelepasan asam lemak bebas (ALB) yang akan ditimbun di hati, otot skelet, dan sel $\beta$ pankreas yang pada akhirnya menyebabkan keadaan hiperglikemia dan hiperinsulinemia. Keadaan hiperinsulinemia pada obesitas sentral ini menunjukkan penurunan sensitivitas insulin atau resistensi insulin. Penurunan sensitivitas insulin perifer ini terbukti berhubungan dengan lemak viseral (8).

Hasil penelitian ini sesuai dengan penelitian-penelitian sebelumnya di Amerika Serikat yang menunjukkan bahwa remaja dengan TGT memiliki rasio lemak viseral terhadap lemak subkutan yang lebih tinggi dibandingkan dengan yang normal (tanpa TGT) (8). Di lain pihak derajat obesitas sentral berhubungan erat dengan deposisi jaringan lemak viseral abdominal (6). Penelitian ini tidak dapat mengidentifikasi variabel lain sebagai faktor risiko yang berhubungan dengan TGT. Hal ini kemungkinan disebabkan karena besar sampel yang kurang untuk analisis odds ratio (OR).

Luaran sekunder penelitian ini adalah lebih dari separuh subjek mengalami abnormalitas glukosa darah (56\% atau 35 dari 62 subjek). Prevalensi TGT penelitian ini adalah sebesar 23\% (14 dari 62 subjek), lebih rendah dibandingkan dengan penelitian sebelumnya yang dilakukan di Jerman (12) dan Amerika Serikat (13) yang melaporkan prevalensi sebesar $62,7 \%$ dan $57,5 \%$. Hal ini mungkin disebabkan oleh adanya perbedaan etnis, selain itu pada penelitan di Jerman menggunakan kriteria obesitas yang lebih tinggi (Centers for Disease Control/CDC 2000) dan kisaran umur yang berbeda (7-18 tahun).

Penelitian ini juga mendapatkan subjek dengan glukosa puasa terganggu (GPT) yang cukup tinggi yaitu total 21 dari 62 subjek. Subjek yang mengalami GPT dan glukosa 2 jam pasca pembebanan terganggu (GPT+TGT) didapatkan sebesar 1 dari 62 subjek. Penelitian ini tidak mendapatkan subjek yang memenuhi kriteria DM. Dari semua kelompok abnormalitas glukosa darah, hanya TGT yang menunjukkan perbedaan prevalensi di antara kedua kelompok obesitas.

Hasil penelitian ini berbeda dengan laporan penelitian sebelumnya di Jerman dan Amerika Serikat yang menunjukkan bahwa prevalensi TGT lebih tinggi daripada prevalensi GPT $(12,13,14)$, penelitian ini mendapatkan kondisi yang sebaliknya. Faktor yang menyebabkan adanya perbedaan hasil penelitian ini dengan penelitian sebelumnya adalah karena perbedaan etnis, metode pemeriksaan, dan perbedaan kelompok umur subjek. 
Beberapa peneliti telah mengidentifikasi dasar kelainan pada TGT dan GPT maupun kombinasi TGT+GPT. Pada subjek dengan TGT selain terjadi resistensi insulin yang ditandai dengan penurunan sensitivitas insulin, baik di perifer maupun terhadap produksi glukosa hepatik, juga disertai penurunan sekresi insulin fase I, tetapi tidak disertai penurunan sekresi insulin fase II $(13,14,15)$. Subjek dengan GPT mengalami penurunan sekresi insulin yang lebih berat karena terjadi pada fase I maupun II (14). Namun demikian berbeda dengan TGT, pada GPT tidak didapatkan penurunan sensitivitas insulin perifer tetapi didapatkan penurunan sensitivitas terhadap glukosa pada sekresi insulin fase pertama. TGT dan GPT keduanya memiliki basis patofisiologi yang sama yaitu penurunan sekresi insulin atau disfungsi sel beta dengan tingkat yang berbeda tetapi pada TGT disertai dengan resistensi insulin. Pada GPT + TGT selain terjadi penurunan sekresi insulin pada fase I dan II juga dijumpai penurunan sensitivitas insulin perifer (14). Dari ketiga kelompok glukosa darah abnormal tersebut kondisi GPT+TGT merupakan kondisi terberat disusul oleh kelompok GPT dan kemudian TGT.

\section{KESIMPULAN DAN SARAN}

Prevalensi TGT pada obesitas sentral lebih besar daripada obesitas non sentral dan obesitas sentral merupakan faktor risiko kejadian TGT yang meningkatkan risiko menjadi TGT sebesar 4,6 kali lipat dibandingkan obesitas non sentral. Penelitian-penelitian sebelumnya menunjukkan bahwa TGT merupakan kondisi pradiabetes, sehingga penderita TGT sangat mungkin akan berkembang menjadi penderita diabetes mellitus klinis dalam jangka waktu yang tidak terlalu lama.

Oleh karena itu pengukuran lingkar pinggang diikuti pemeriksaan kadar glukosa darah puasa dan 2 jam pasca pembebanan mungkin dapat menjadi bagian dari monitor rutin siswa perempuan dengan obesitas sentral.

\section{RUJUKAN}

1. World Health Organization. Obesity: preventing and managing the global epidemic. Geneva: Report of a WHO Consultation; 2000.

2. Huriyati E. Studi kohort prevalensi obesitas siswa-siswi sekolah lanjutan tingkat pertama (SLTP) Kota Yogyakarta. Jurnal Gizi Klinik Indonesia 2006;3(1):1-5.

3. McCarthy HD, Ellis SM, Cole TJ. Central overweight and obesity in British youth aged 11-16 years: cross sectional surveys of waist circumference. BMJ 2003;326(7390):624.

4. Moreno LA, Fleta J, Mur L, Sarria A, Bueno M. Fat distribution in obese and nonobese children and adolescents. J Pediatric Gastroenterol Nutr 1998;27(2):176-80.

5. Alberti KGMM, Zimmet P, Kaufman F, Tajima N, Silink M, Arslanian S, Wong G, Bennett P, Shaw J, Caprio $S$. The IDF consensus definition of the metabolic syndrome in children and adolescent, International Diabetes Federation [serial online] 2007 [cited 2010 March 03]. Available from: http:///www.idf.

6. Wajchenberg BK. Subcutaneous and visceral adipose tissue: their relation to the metabolic syndrome. Endocr Rev 2000;21(6):697-738.

7. Freemark M. Metabolic consequences of obesity and their management. In: BrookCGD,Clayton PE, BrownRS. Clinical pediatric endocrinology, $5^{\text {th }}$ edition. London: Blackwell Publishing; 2005.

8. Weiss R, Duforu S, Taksali SE, Tamborlane WV, Petersen KF, Bonadonna RC, Boselli L, Barbetta G, Allen K, Rife F, Savoye M, Dziura J, Sherwin R, Shulman GI, Caprio S. Prediabetes in obese youth: a syndrome of impaired glucose tolerance, severe insulin resistance, and altered myocelluller and abdominal fat partitioning. Lancet 2003;362(9388):951-7.

9. Sastroasmoro $S$, Ismael S. Dasar-dasar metodologi penelitian klinis, edisi ketiga. Jakarta: CV Sagung Seto; 2008.

10. Damanik SM. Klasifikasi bayi menurut berat lahir dan masa gestasi. Dalam: Kosim MS, Yunanto A, Dewi R, Sarosa GI, Usman A. Buku Ajar Neonatologi, edisi pertama. Jakarta: Badan Penerbit IDAl; 2008.

11. Ryha $\mathrm{NH}$. Hubungan antara lingkar pinggang dan rasio lingkar pinggang-panggul dengan resistensi insulin pada remaja putri obes di Yogyakarta [Skripsi]. Yogyakarta: Fakultas Kedokteran Universitas Gadjah Mada; 2009.

12. Wiegand $S$, Maikowski U, Blankenstein $O$, Biebermann H, Tarnow P, Gruters A. Type 2 diabetes and impaired glucose tolerance in European children and adolescents with obesity - a problem that is no longer restricted to minority groups. Eur J Endocrinol 2004;51:199-206.

13. Cali AMG, Bonadonna RC, Trombetta M, Weiss, Caprio S. Metabolic abnormalities underlying the different prediabetic phenotypes in obese adolescents. J Clin Endocrinol Metab 2008;93:1767-73.

14. Bacha F, Lee SJ, Gungor N, Arslanian SA. From prediabetes to type 2 diabetes in obese youth: pathophysiological characteristic along the spectrum of glucose dysregulation. Diabetes Care 2010;33:222531.

15. Tfayli $\mathrm{H}$, Arslanian SA. Pathophysiology of type 2 diabetes mellitus in youth: the evolving chameleon. Arq Bras Endocrinol Metab 2009;53(2):165-74. 